\title{
Ticlopidine induced colitis: a histopathological study including apoptosis
}

\author{
D Berrebi, A Sautet, J-F Flejou, M-C Dauge, M Peuchmaur, F Potet
}

Services d'Anatomie et de Cytologie Pathologiques, Hôpital Bichat, Paris, France

D Berrebi

A Sautet

M-C Dauge

F Potet

Services d'Anatomie et de Cytologie

Pathologiques, Hôpital

Beaujon, Paris, France J-F Flejou

Services d'Anatomie et de Cytologie

Pathologiques, Hôpital

Robert Debré, Paris,

France

M Peuchmaur

Correspondence to:

Dr D Berrebi, Service

d'Anatomie et de Cytologie

Pathologiques, Hôpital

Robert Debré, 48 bd

Sérurier, 75019 Paris,

France.

Accepted for publication

13 January 1998

Table 1 Patients treated with ticlopidine - clinical characteristics

\begin{tabular}{lllllll}
\hline Patient & $\begin{array}{l}\text { Age } \\
\text { (years) }\end{array}$ & Sex & $\begin{array}{l}\text { Duration of } \\
\text { diarrhoea } \\
\text { (weeks) }\end{array}$ & $\begin{array}{l}\text { Bowel } \\
\text { movements } \\
\text { each day }\end{array}$ & $\begin{array}{l}\text { Abdominal } \\
\text { pain }\end{array}$ & Weight loss \\
\hline 1 & 69 & $\mathrm{M}$ & 8 & $3-5$ & - & - \\
2 & 73 & $\mathrm{M}$ & 4 & $3-4$ & - & - \\
3 & 65 & $\mathrm{M}$ & 4 & $3-4$ & - & + \\
4 & 62 & $\mathrm{M}$ & 8 & $2-3$ & - & - \\
5 & 69 & $\mathrm{M}$ & 12 & $3-4$ & - & - \\
6 & 77 & $\mathrm{M}$ & 4 & $4-5$ & - & - \\
7 & 78 & $\mathrm{M}$ & 4 & $3-4$ & - & - \\
8 & 76 & $\mathrm{~F}$ & 4 & $2-3$ & + & + \\
9 & 60 & $\mathrm{~F}$ & 5 & $3-4$ & - & - \\
\hline
\end{tabular}

Conclusion-Microscopic colitis can be induced by ticlopidine and is accompanied by an increase in epithelial apoptosis. Hence, increased apoptosis might be related to drug injury or might be part of microscopic colitis.

(f Clin Pathol 1998;51:280-283)

Keywords: apoptosis; microscopic colitis; ticlopidine

Microscopic colitis is a clinical-pathological syndrome characterised by chronic diarrhoea, normal endoscopy, but mild inflammatory changes in the colonic mucosa. ${ }^{1}$ These changes have been linked to the use of certain drugsfor example, microscopic colitis has been

\begin{abstract}
Aims-To describe ticlopidine related microscopic colitis and to assess the occurrence of apoptosis in the colon epithelium. Methods-A series of colorectal biopsy samples from nine patients with ticlopidine related chronic diarrhoea were analysed. Biopsies were also taken from five of these patients between two and four months after ticlopidine withdrawal. The number of apoptotic cells in the crypts/ $\mathbf{m m}^{2}$ (apoptotic index) was calculated using in situ labelling by terminal deoxyribonucleotidyl transferase (TdT) mediated dUTP-biotin nick end labelling (TUNEL). All specimens were matched to normal colorectal specimens from a control group of comparable age and sex distribution.

Results-Histological examination of the colon biopsy specimens taken from all nine patients with ticlopidine related chronic diarrhoea showed characteristic features of microscopic colitis. The histology returned to normal when ticlopidine was withdrawn. Apoptotic cells were rarely found in controls, and the mean apoptotic index was 0.53 . The apoptotic index was significantly higher (16.53) in ticlopidine related colitis, but decreased dramatically to control value when ticlopidine was withdrawn.
\end{abstract} onset of diarrhoea. Endoscopic examination showed the colonic mucosa to be normal in all cases. Two biopsies were taken from the sigmoid colon and rectum.

Ticlopidine was withdrawn, and the diarrhoea disappeared in all nine patients over the next five to seven days. A colonoscopic examination with biopsy was performed in five patients two to four months after drug withdrawal.

The controls were a series of 10 histologically normal colon biopsy specimens from 


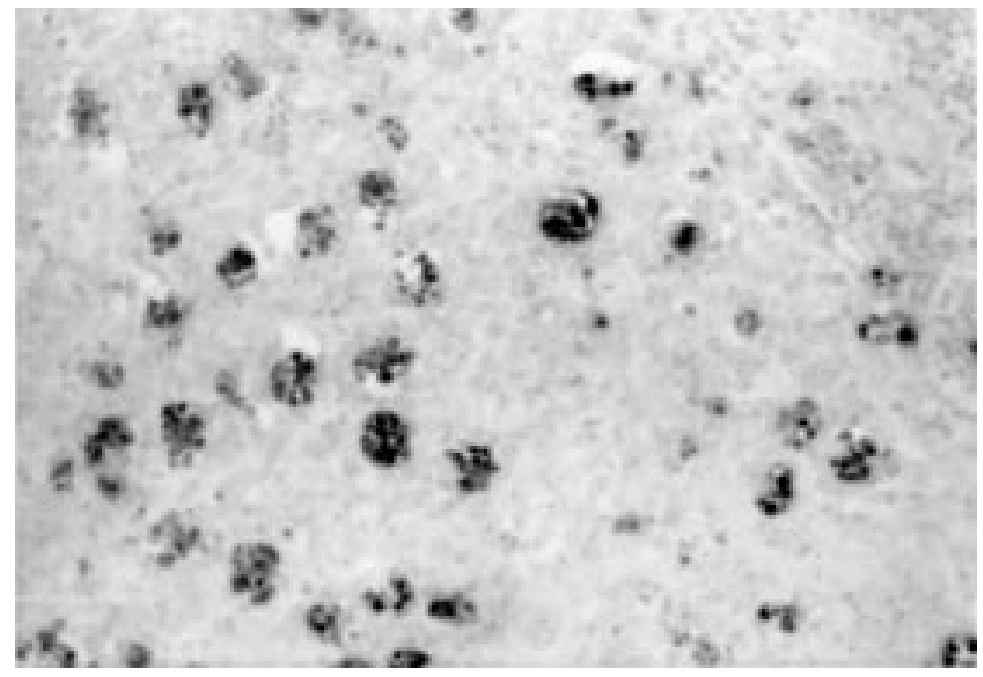

Figure 1 Staining of embedded tissue section for apoptosis by the terminal deoxyribonucleotidyl transferase (TdT) mediated dUTP-biotin nick end labelling (TUNEL) method. Fragmented DNA is indicated by dark staining. Reactive lymph node: there are many apoptotic bodies in the germinal centres (original magnification $\times 600$.)

patients of comparable age and sex who were suffering from non-specific abdominal pain or had received an intestinal bypass for obesity. Patients with diarrhoea or taking drugs were excluded.

HISTOLOGICAL EXAMINATION

All specimens were fixed in neutral buffered formalin and embedded in paraffin wax. Paraffin wax sections $(5 \mu \mathrm{m})$ were cut, pretreated with $0.01 \%$ aqueous solution of poly-l-lysine, and stained with haematoxylin and eosin, and picrosirius. The sections were analysed for surface epithelium, lamina propria, crypts, and subepithelial collagen layer.

TUNEL EXAMINATION

A modification of the TUNEL method of Gavrieli et al was used to detect apoptotic cells in situ. ${ }^{11}$ Briefly, the $5 \mu \mathrm{m}$ sections were deparaffinised and rehydrated; the nuclei were then stripped of protein by incubation with $0.4 \%$ pepsin (Sigma, St Louis, USA) for 35 minutes at room temperature. This incubation time produced optimal results for colorectal samples. Terminal deoxyribonucleotidyl transferase (TdT) (Amersham, High Wycombe, Bucks, UK) (final concentration $0.25 \mathrm{U} / \mathrm{ml}$ ) was used to link biotin-11 dUTP (Boehringer, Mannheim, Mannheim, Germany) to the ends of the DNA fragments. The signal was amplified by streptavidin-alkaline phosphatase and stained with fast red for 15 minutes at room temperature. Cells or apoptotic bodies stained red indicated the presence of fragmented DNA. The TdT reaction step was omitted for negative controls, and no non-specific reaction was seen. Apoptotic bodies within the germinal centres of lymph nodes were used as positive controls. The TUNEL method was used to examine biopsies from patients being treated with ticlopidine and biopsies taken after ticlopidine had been withdrawn.

MORPHOMETRIC ANALYSIS

All the positive cells found in the epithelium of each biopsy section were counted at high mag- nification $(\times 400)$. The crypt epithelium was then analysed quantitatively using a computer assisted technique. Images of the TUNEL specimens under a Leitz photomicroscope were sent via an IEC 800 CC colour video camera to a 486 PC computer with a digitalisation card (Cyclope; Digital Vision, Systèmes Sud, Toulouse, France). The signal was displayed on a video monitor (Sony Trinitron PVM 1440, $738 \times 512$ pixels; Tokyo, Japan). The slides were studied at $\times 400$ magnification (a pixel $=0.276 \mu \mathrm{m}$ ). The area of the crypts was measured using morphometric software (ERESILAB; Rana Inc, Palaiseau, France). The number of apoptotic cells in the crypts $/ \mathrm{mm}^{2}$ or the apoptotic index was calculated. Because the surface epithelium was damaged in the specimens from patients with ticlopidine related colitis, apoptotic cells were not counted in the surface epithelium.

\section{STATISTICAL METHODS}

The results were analysed using the KruskalWallis and Mann-Whitney tests.

\section{Results}

Histological examination of the colon biopsy specimens from all nine patients with ticlopidine related chronic diarrhoea showed characteristic features of microscopic colitis, with increased numbers of intraepithelial lymphocytes, eosinophils and neutrophils, granulocytes in the surface epithelium, and injury to the surface epithelium such as flattening of surface cells, epithelial detachment, and loss of epithelial cells. There was some infiltration of crypts by lymphocytes and eosinophils, but no crypt damage. The number of inflammatory cells in the lamina propria was increased. The lamina propria was frequently infiltrated with eosinophils. The inflammatory infiltrate was more pronounced in the upper part of the mucosa than in the deeper part. The thickness of the collagen subepithelial layer was within the normal range of 5-7 $\mu \mathrm{m}$ in all the sections. ${ }^{1}$

Detection of genomic fragmentation by TUNEL resulted in intense nuclear staining of apoptotic cells and apoptotic bodies in the germinal centres of lymph nodes (fig 1). TUNEL revealed a distinct pattern of nuclear staining in the specimens of ticlopidine related microscopic colitis, with staining typically confined to a cluster of neighbouring crypts, while other areas of the mucosa were negative. TUNEL labelled cells were morphologically intact cells undergoing apoptosis, cells showing chromatin condensation at the nuclear periphery, or cells with fragmented nuclei (fig $2 \mathrm{~A}$ ). The apoptotic index was calculated for all the colonic biopsy specimens (table 2). The specimens of ticlopidine related colitis had a mean apoptotic index of 16.53 (range, 7.41-33.68). There were few if any apoptotic cells in the crypts of the control group, and the mean apoptotic index was 0.53 (range, 0-2.67). The five specimens taken after ticlopidine withdrawal all had a histologically normal mucosa and the mean apoptotic index had decreased dramatically to control values (fig 2B). 


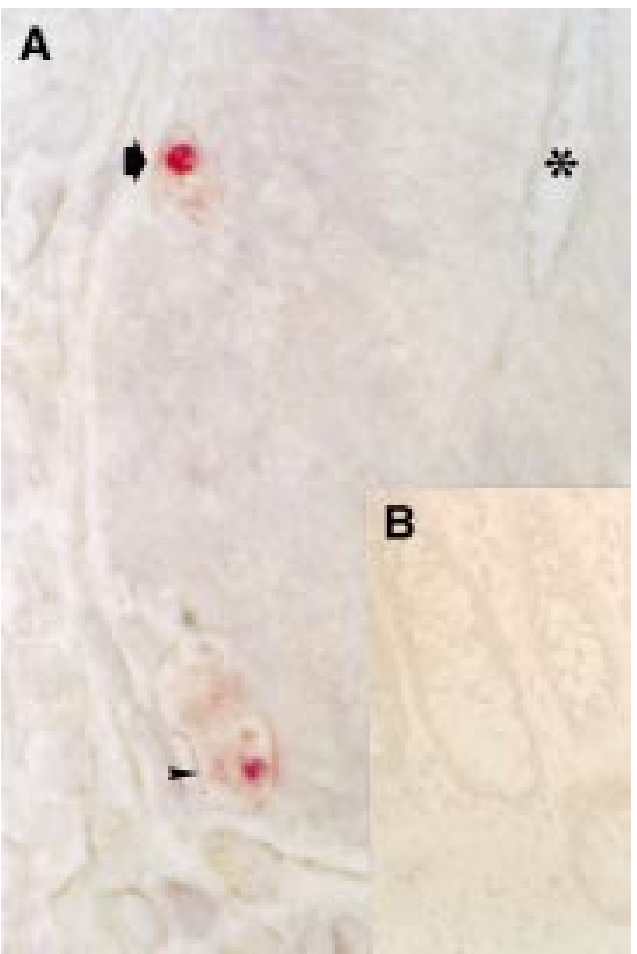

Figure 2 Staining of embedded tissue section for apoptosis by the terminal deoxyribonucleotidyl transferase (TdT) mediated dUTP-biotin nick end labelling (TUNEL) method. Fragmented DNA is indicated by red staining. (A) A patient with ticlopidine induced colitis. There are two apoptotic cells in the colonic crypt. Note the chromatin condensation at the nuclear periphery (arrow) and nuclear fragmentation (arrowhead). The lumen is indicated by an asterisk (original magnification $\times 1200$ ). (B) Same patient after ticlopidine was withdrawn. There are no apoptotic cells in the colonic crypts (original magnification $\times 250$ ).

Table 2 Incidence of crypt apoptosis

\begin{tabular}{lcl}
\hline & $\begin{array}{l}\text { No of } \\
\text { patients }\end{array}$ & $\begin{array}{l}\text { Apoptotic index } \\
\text { (mean (SD)) }\end{array}$ \\
\hline Controls & 10 & $0.53(0.92)$ \\
Ticlopidine induced colitis & 9 & $16.53(9.6)$ \\
Ticlopidine withdrawn & 5 & $1.96(1.83)$ \\
\hline Apoptotic index, apoptotic cells $/ \mathrm{mm}^{2}$ &
\end{tabular}

The apoptotic index of patients with ticlopidine related colitis was significantly greater than that found in the control group, or the ticlopidine withdrawal group $(\mathrm{p}=0.000145)$. In contrast, there was no statistical difference between the apoptotic indices of the control and ticlopidine withdrawal groups $(\mathrm{p}=0.55)$.

\section{Discussion}

Microscopic colitis is a pathological syndrome of chronic watery diarrhoea, with diffuse inflammation of the colonic mucosa, but normal colonic endoscopy. ${ }^{1}$ The aetiology of microscopic colitis is unknown, but recent reports suggest that it may be induced by drugs such as the non-steroidal anti-inflammatory drugs Cyclo 3 fort $^{12-14}$ or ranitidine. ${ }^{15}$

Ticlopidine is a potent inhibitor of platelet aggregation induced by ADP. ${ }^{16}$ One of its frequent side effects is a transient moderate diarrhoea, but a few cases of chronic, severe diarrhoea have been reported. ${ }^{2}{ }^{17}{ }^{18}$ Only isolated cases of ticlopidine related diarrhoea have been documented histologically, and they have shown a typical microscopic colitis pattern. ${ }^{19} 20$ Histological examination of the colon biopsy specimens from our nine cases of ticlopidine related diarrhoea showed characteristic features of microscopic colitis with increased numbers of lymphocytes, eosinophils, and neutrophils, granulocytes in the surface epithelium and in the lamina propria, and damage to the surface epithelium. The lamina propria was frequently infiltrated by eosinophils.

Recently, Lee suggested that the increased number of apoptotic cells in colon crypts could be a result of a drug effect. ${ }^{89}$ This phenomenon has mostly been described with cytotoxic drugs, ${ }^{21}$ but cases have been reported for other classes of drugs, such as cyclosporin A and gold salt. $^{22}{ }^{23}$ Crypt apoptosis is not caused specifically by drugs, as it also occurs in infectious diseases $^{24}$ and in ulcerative colitis. ${ }^{25}$ Nevertheless, it is instructive to examine apoptosis in drug related microscopic colitis using the sensitive TUNEL method.

DNA fragmentation is considered to be the most characteristic feature of programmed cell death, ${ }^{6}$ and it can be found not only in histologically defined apoptotic cells, but also in morphologically intact cells undergoing apoptosis. ${ }^{26}$ The TUNEL method is based on the direct in situ labelling of DNA breaks and is more sensitive than the standard staining methods when combined with cell morphology. Slides stained with haematoxylin and eosin show only apoptotic bodies that have reached the end of apoptosis, just before they are phagocytosed by macrophages or neighbouring epithelial cells. Cells appear apoptotic only for a few minutes, so that it may be difficult to distinguish between intraepithelial neutrophils and apoptotic bodies, which may distort the results.

The TUNEL method showed increased apoptosis in ticlopidine related microscopic colitis. The apoptotic index was significantly greater in all the nine patients with ticlopidine related microscopic colitis than in the control group. Furthermore, the five cases who were biopsied after ticlopidine was withdrawn showed a dramatic decrease in apoptotic index while the biopsies were histologically normal.

The relation between apoptosis, ticlopidine, and microscopic colitis is unclear. Apoptosis may be the result of direct toxicity caused by ticlopidine, as in the agranulocytosis due to this drug. ${ }^{27}$ Ticlopidine could also cause apoptosis indirectly via a cell mediated process. All the patients treated with ticlopidine have above normal numbers of eosinophils and lymphocytes in the lamina propria. Ticlopidine has been also associated with villus atrophy and lymphocytic gastritis. ${ }^{19}$ These mucosal inflammatory cells were unlikely to be attracted by apoptotic epithelial cells, because apoptotic cells are phagocytosed as soon as the DNA damage begins. On the contrary, inflammatory cells, and particularly $\mathrm{T}$ lymphocytes, could trigger the cascade of events that results in cell apoptosis. This cell mediated apoptosis could involve the perforines, granzyme $\mathrm{B} / \mathrm{TiA} 1$ or CD95 (Fas) systems ${ }^{28}{ }^{29}$; Fas is expressed by several human cells including fibroblasts, $\mathrm{T}$ 
lymphocytes, myeloid cells, and the normal colon epithelium, ${ }^{30-32}$ and could be dramatically deregulated in certain pathological conditions. ${ }^{33}$ It is always possible that apoptosis is part of the general histological picture of microscopic colitis. A study of apoptosis in a large series of idiopathic microscopic colitis would help to clarify this point.

Thus, microscopic colitis may be induced by ticlopidine and is accompanied by an increase in epithelial cell apoptosis, as reported for ranitidine related colitis. ${ }^{34}$ Further studies are needed to see if the same phenomenon occurs in other drug induced colitis and in drug related diarrhoea with an apparently normal colon mucosa.

1 Bogomoletz WV. Collagenous, microscopic and lymphocytic colitis. An evolving concept. Virchows Archiv 1994;424:573-9.

2 Chassany O, Bacq Y, Metman EH, et al. Severe chronic diarrhea during treatment with ticlopidine. Gastroenterol Clin Biol 1989;13:950.

3 Hoffman HS, Butensky MS. Severe diarrhea with ticlopidine therapy. Conn Med 1994;58:251.

4 Giardina MG, Matarazzo M, Cacciatore L, et al. Ticlopidine can cause chronic diarrhea. Lancet 1984;1:407.

5 Wyllie AH, Morris RG, Smith AL, et al. Chromatin cleavage in apoptosis: association with condensed chromatin morphology and dependence on macromolecular synthesis. $f$ Pathol 1984;142:67-77.

6 Barry MA, Behnke CA, Eastman A. Activation of programmed cell death (apoptosis) by cisplatine, other anticancer drugs, toxins and hyperthermia. Biochem Pharmacol 1990;40:2353-62.

7 Searle J, Lawson TA, Abbott PJ, et al. An electronmicroscopic study of the mode of cell death induced by microscopic study of the mode of cell death induced by cancer-chemotherapeutic agents in populations of proliferatin

8 Lee FD. Importance of apoptosis in the histopathology of drug related lesions in the large intestine. $f$ Clin Patho 1993;46:118-22.

Lee FD. Drug-related pathological lesions of the intestinal tract. Histopathology 1994;25:303-8.

10 Walker NI, Bennett RE, Axelsen RA. Melanosis coli. A consequence of anthraquinone induced apoptosis of colonic epithelial cells. Am ₹ Pathol 1988;131:465-76.

11 Gavrieli Y, Sherman Y, Ben-Sasson SA. Identification of programmed cell death in situ via specific labeling of nuclear DNA fragmentation. F Cell Biol 1992;119:493501.

12 Ouyahya F, Codjovi P, Machet MC, et al. Diarrhea induced by Cyclo 3 Fort (R) and lymphocytic colitis. Gastroenterol by Cyclo 3 Fort (R) and
Clin Biol 1993;17:65-6.

13 Beaugerie L, Luboinski J, Brousse N, et al. Drug induced lymphocytic colitis. Gut 1994;35:426-8.

14 Riddell RH, Tanaka M, Mazzoleni G. Non-steroidalal antiinflammatory drugs as a possible cause of collagenous colitis: a case control study. Gut 1992;33:683-6.
15 Beaugerie L, Patey N, Brousse N. Ranitidine, diarrhoea, and lymphocytic colitis. Gut 1995;37:708-11.

16 Saltiel E, Ward A. Ticlopidine. A review of its pharmacodynamic and pharmacokinetic properties, and therapeutic efficacy in platelet-dependent disease states. Drugs 1987; 34:222-62.

17 Guédon C, Bruna T, Ducrotté P, et al. Severe diarrhea caused by Ticlid associated with disorders of small intestine motility. Gastroenterol Clin Biol 1989;13:934-7.

18 Diaz Morant V, Molina Ruano FJ, Manteca Gonzalez R, et al. Chronic diarrhea and ticlopidine. Gastroenterol Hepatol 1995;18:354-5

19 Ruget O, Burtin P, Cerez H, et al. Chronic diarrhea associated with villous atrophy and lymphocytic gastritis, caused by ticlopidine. Gastroenterol Clin Biol 1992;16:290.

20 Martinez Aviles P, Gisbert Moya C, Berbegal Serra J, et al. Ticlopidine-induced lymphocytic colitis. Med Clin 1996; 106:317.

21 Cunningham D, Morgan RJ, Mills PR, et al. Functional and structural changes of the human proximal small intestine after cytotoxic therapy. F Clin Pathol 1985;38:265-70.

22 Murphy EA, Morris J, Walker E, et al. Cyclosporine A induced colitis and acquired selective IgA deficiency in a patient with juvenile chronic arthritis. $f$ Rheumatol 1993;20:1397-8.

23 Wong V, Wyatt J, Lewis F, et al. Gold-induced enterocolitis complicated by cytomegalovirus infection: a previously unrecognised association. Gut 1993;34:1002-5.

24 Kotler DP, Weaver SC, Terzakis JA. Ultrastructural features of epithelial degeneration in rectal crypts of patients with AIDS. Am f Surg Pathol 1986;10:531-8.

25 Iwamoto M, Koji T, Makiyama K, et al. Apoptosis of crypt epithelial cells in ulcerative colitis. F Pathol 1996;180:152-

26 Umansky SR. The genetic program of cell death. Hypothesis and some application: transformation, carcinogenesis, ageing. F Theor Biol 1982;97:591-602.

27 Bedani PL, Fiocchi O, Scapoli PI, et al. Leukopenia due to ticlopidine in a patient with chronic renal failure. Haematologica 1984;69:641-2.

28 Rouvier E, Luciani MF, Goldstein P. Fas involvement-in Ca (2+)-independent $\mathrm{T}$ cell mediated cytotoxicity. $\mathcal{F} \operatorname{Exp} \mathrm{Med}$ 1993;177:195-200.

29 Yonehara S, Ishii A, Yonehara M. A cell killing monoclonal antibody (anti-Fas) to a cell surface antigen codownregulated with the receptor of tumor necrosis factor. $\mathcal{F}$ Exp Med 1989;169:1747-56.

30 Itoh N, Yonehara S, Ishii A, et al. The polypeptide encoded by the cDNA for human cell surface antigen Fas can mediate apoptosis. Cell 1991;66:233-43.

31 Owen-Schaub LB, Yonehara S, Crump WL 3rd, et al. DNA fragmentation and cell death is selectively trigerred in activated human lymphocytes by Fas antigen engagement. Cell Immunol 1992;140:197-205.

32 Moller P, Koretz K, Leithauser F, et al. Expression of APO-1 (CD 95), a member of the NGF/TNF receptor superfamily, in normal and neoplastic colon epithelium. Int $\mathcal{F}$ Cancer 1994;57:371-7.

33 Larousserie F, Berrebi D, Florentin A, et al. Downregulation of CD95 (FAS-APO-1) in the epithelia of adenovirus-infected appendices. Histopathology 1997;31: $342-6$.

34 Beaugerie L, Berrebi D, Dikov D, et al. Epithelial apoptosis as a very early marker of drug-induced colitis: the example of ranitidine. Gastroenterol Clin Biol 1996;20:918-9. 